\title{
Biologists urge US to build marine reserves
}

\section{Mark Schrope, San Francisco}

Protected 'marine reserves' off the coasts of the United States received unequivocal support this week in a statement issued by 160 prominent marine scientists. The group declared that there is now evidence that these reserves are effective as conservation tools.

The statement was crafted by the National Center for Ecological Analysis and Synthesis at the University of California at Santa Barbara, and was released at the annual meeting of the American Association for the Advancement of Science in San Francisco. It was issued in response to indications that the US government is preparing to stall plans to establish a network of the reserves.

"The message is clear," says Jane Lubchenco, a marine biologist at Oregon State University and one of the statement's signatories. "Marine reserves work, they work quickly, and they are a powerful and underutilized tool. Existing scientific information justifies immediate application of networks of marine reserves as a central management tool," she says.

In May of last year, former president Bill Clinton issued an executive order requiring a study of marine protected areas, where some activities are prohibited. The executive order also called for the planning of a network of such areas, probably including a small area of 'marine reserves', where no resource removal of any kind is permitted.

But in January, James Hansen (Republican, Utah), the new chairman of the powerful resources committee in the House of Representatives, sent a letter to the incoming administration of President George W. Bush. In it, he urged Bush to slow down any movement towards a network of marine protected areas, due to what he termed insufficient knowledge on their effectiveness.

Lubchenco says that, although a few years ago this was the case, the present state of knowledge makes it clear that the marine reserves would work.

The latest statement was released in conjunction with the results from several marine reserve studies to be published in a forthcoming issue of Ecological Applications. One, led by Robert Warner of the University of California at Santa Barbara, examined data on 81 marine reserves around the world and found almost universal and dramatic increases in population densities, organism size and species diversity within the reserves.

Roger Griffis, policy adviser for the National Oceanic and Atmospheric Administration, says that fishermen are still concerned that reserves will harm their business. But he notes that reserves may actually prevent further declines in catches.

Griffis adds that the decline of marine

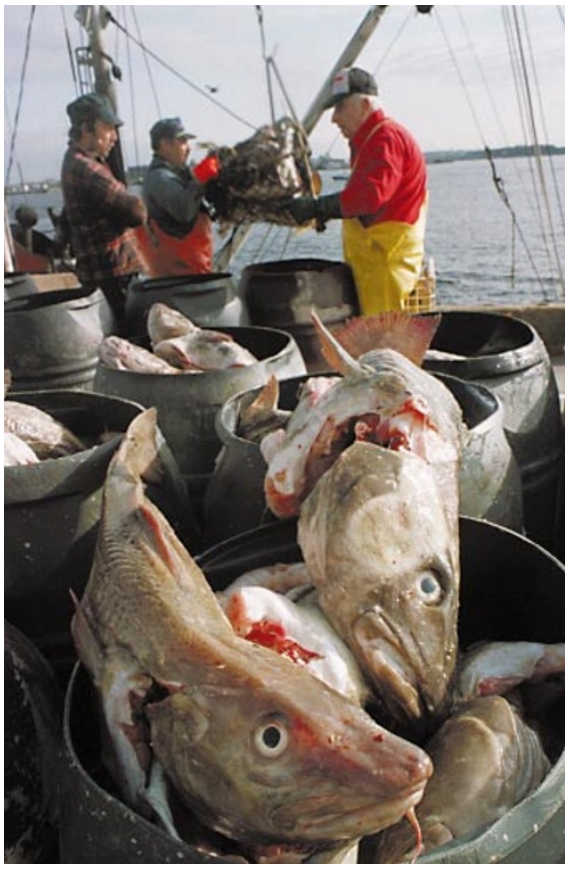

Economies of scale: marine reserves could reverse declines in fish stocks, researchers say.

resources has reached a critical point and that, although study of reserves should continue, the recent studies amply show their effectiveness. "We do know enough to be acting," he says.

\section{Scientists seek solidarity in oaths}

Paul Smaglik and Colin Macilwain, San Francisco Should scientists, like medical doctors, pledge to do no harm? The question, which has largely lain dormant for years, was revisited this week by US researchers.

A symposium held at the annual meeting of the American Association for the Advancement of Science (AAAS) in San Francisco considered the merits of adapting the Hippocratic oath to encompass all scientific disciplines.

Proponents say such an oath would help to regain public trust. But opponents say that it might cut off avenues of scientific inquiry that may eventually benefit society.

The movement to adopt oaths peaked in the United States during the nuclear arms race. It has now resurfaced in Europe, largely as a result of public concern about the role of science in the bovine spongiform encephalopathy debacle and in genetically modified food.

French scientists are seriously considering the merits of scientific oaths, says Gerard Toulouse, a scientific director at the Laboratoire de Physique Théorique de l'École
Normal Supérieure in Paris. He says they might provide an impetus to make scientists more conscious of their public duty.

But Irving Lerch, head of international affairs for the American Physical Society, is not sure that oaths will win public trust. He says it is hard for scientists to pledge to work only for the public good when they can predict neither the outcome of their research nor how someone else might apply it. And to be of any use, he notes, an oath would have to be enforced by someone. Scientific societies seem reluctant to take on such a role.

But a few blocks away from the crowded AAAS meeting, a clutch of pressure groups and scientists called on researchers to sign a pledge right now, disavowing work on all weapons of mass destruction.

One pledge supporter, Greg Mello of the Los Alamos Study Group, says that societies such as the AAAS - which declined to accommodate the pledge press conference - have vague discussions about oaths, but "shy away from anything that might affect peoples' careers".

http://www.lasg.org/pledge

\section{Climate change offers bleak future}

Quirin Schiermeier, Munich

Global warming is damaging natural systems across the whole planet, according to a report from the international group of scientists charged with studying climate change.

All continents will suffer economically, the report says, but Africa, Asia, South America and the small island states will be most affected.

The report is the second in a series of three from the Intergovernmental Panel on Climate Change (IPCC). Some natural systems, including glaciers and coral reefs, "may undergo significant and irreversible damage", the panel says.

In particular, the scientists predict a reduction in crop yields in warm countries, decreased water availability in regions where water is already scarce, an increase in flooding risks, and the spread of diseases such as malaria and cholera.

The "impacts of future changes in climate extremes are expected to fall disproportionately on the poor", they add. 